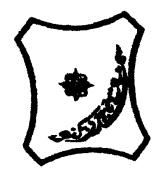

Bayero Journal of Pure and Applied Sciences, 9(1): 191 - 196

Received: April, 2016

Accepted: June, 2016

ISSN $2006-6996$

\title{
ANTIPLASMODIAL STUDIES ON THE ETHYL ACETATE FRACTION OF THE STEM BARK EXTRACT OF Uapaca togoensis PAX. (EUPHORBIACEAE) IN MICE
}

\author{
${ }^{*}$ Olorukooba, A.B. ${ }^{1}$, Maiha, B.B. ${ }^{1}$, Chindo, B.A., ${ }^{1,2}$ Ejiofor, J. $^{1}$ and Hamza, A. N. ${ }^{3}$ \\ ${ }^{1}$ Department of Pharmacology and Therapeutics, Ahmadu Bello University, Zaria, Nigeria. \\ ${ }^{2}$ Department of Pharmacology, Kaduna State University, Kaduna, Nigeria. \\ ${ }^{3}$ Department of Pharmaceutical and Medicinal Chemistry, Ahmadu Bello University, Zaria, Nigeria. \\ *email - aolorukooba@gmail.com, \\ Phone no - +2348057665703
}

\begin{abstract}
Uapacatogoensis of family Euphorbiaceae, has been used folkorically for the treatment of various ailments including pneumonia, cough, fever, rheumatism, vomitting and epilepsy. The ethyl acetate fraction of the stem bark was analyzed for antiplasmodial activity in mice. Acute toxicity of the extract was studied Lorke's method. Suppressive activity, curative and prophylactic effect was studied in chloroquine-sensitive Plasmodium berghei NK 65 infected mice. Five groups, of six mice in each group were used. Group 1 was administered with $0.2 \mathrm{ml}$ distilled water only; groups 2, 3 and 4 were administered with 250, 500, and $1000 \mathrm{mg} / \mathrm{kgethyl}$ acetate fraction of Uapacatogoensis respectively, while group 5 was administered with $5 \mathrm{mg}$ chloroquine/kg body weight. The doses were all administered orally. All doses of the extract produced significant, dose dependent, chemo suppressive activity against the parasite in the suppressive, curative and prophylactic tests. This was comparable to the group treated with chloroquine. The extract also prolonged the mean survival time of treated mice compared to the untreated group. The oral median lethal dose ( $\left.L D_{50}\right)$ of the ethyl acetate fraction in mice was greater than $5000 \mathrm{mg} / \mathrm{kg}$ body weight. The results of this study showed that the ethyl acetate fraction of the stem bark is safe and has antiplasmodial activity.
\end{abstract}

Key words: Acute toxicity, Antiplasmodial, Ethyl acetate fraction,Uapacatogoensis

\section{INTRODUCTION}

Malaria is an infectious disease that has continued to cause mortality and morbidity in the tropics and subtropics (Igweet al., 2012).Malaria is transmitted to people through the bites of infected female Anopheles mosquitoes, blood transfusion, organ transplantation, shared use of needles and syringes that are contaminated with blood or from a mother to her foetus before or during delivery (WHO, 2015). There are five species of Plasmodium that cause malaria in humans: Plasmodium falciparum, Plasmodium vivax, Plasmodium ovale, Plasmodium malariae and Plasmodium knowlesi (Collins, 2012; Tcherniuket al., 2015). Malaria caused by $P$. falciparum is more deadly than that caused by the other species of the malaria parasite (Sarkar, 2009). In Africa,most deaths occur among infants, children, pregnant women, and patients with HIV/AIDS, as well as non-immune migrants, mobile populations and travellers (WHO, 2015).

Medicinal plants since time immemorial have been used as a source of medicine (Horeau and Da silva, 1999). The two main antimalarial drugs in use today were derived from plants that had been used traditionally over the centuries in the treatment of malaria and other diseases - quinine from the bark of Cinchona tree and artemisin from Artemisia annua (Basco et al., 1994, Addis et al., 2001 and Odugbemi et al., 2007).In Ghana, Mali, Nigeria and Zambia, the first line of treatment for $60 \%$ of the children with high fevers, resulting from malaria, is the use of herbal medicines at home (WHO, 2002). The increasing resistance of malaria to orthodox antimalarial drugs and adverse effects associated with the drugs is one of the greatest challenges facing malarial control today (Mendiset al., 2001; Iwuanyanwua et al., 2012). This situation coupled with the high cost and or inacessiblity to effective antimalarial drugsdifficulties has stimulated research into the development of newer and more effective alternatives from the plant kingdom which could be more affordable.

Uapacatogoensis (Pax) family Euphorbaiceae is is a tree about $13 \mathrm{~m}$ high with a short bole, usually without stilt-roots on dry sites, but may be stilted in damp localities, of savanna regions from Senegal to western Cameroon, and in eastern Cameroon to Central African Republic. Sometimes in Sierra Leone it forms nearly pure stands (Burkhill, 1994). 
Bajopas Volume 9 Number 1 June, 2016

Ethnobotanical/pharmacological studies revealed that Uapaca togoensishas a wide range of activities. $U$. togoensis is used for treating female infertility and as a restorative wash against fatigue and for making charcoal (Irvine, 1948). The plant has been used folkorically for the treatment of various ailments including pneumonia, cough, fever, rheumatism, vomitting and epilepsy (Kone et al., 2007). Extracts from different parts of the plant have been used in the treatment of skin diseases (Ajibesin, 2012), Compounds from the fruits of Uapaca togoensis, have been isolated and have shown good anti cancer activity against nine drug sensitive and multidrugresistant cancer cell lines (Kuete et al., 2015). The antifugal and antimicrobial activities of the plant has also been reported (Omachi et al., 2015).

With this view, the present study was executed to investigate the antiplasmodial activity of the ethyl acetate fraction of stem bark extract of Uapaca togoensis in Plasmodium berghei infected mice in order to provide scientific evidence for its use in the therapeutic management of malaria.

\section{MATERIALS AND METHODS \\ Experimental materials \\ Plant material}

The stem bark of Uapaca togoensis were collected in February 2013 from Edumoga district, Okpokwu Local Government Area, Benue state. The plant was identified and authenticated by a botanist in the Department of Biological Sciences, Ahmadu Bello University, Zaria. A voucher specimen with number 1279 was deposited in the herbarium for future reference.

\section{Animals}

Swiss albino mice of both sexes weighing $18-22 \mathrm{~g}$ were obtained from the Animal House of the Department of Pharmacology and Therapeutics, Ahmadu Bello University, Zaria. Animals were maintained under standard environmental conditions with access to standard diet and water ad libitum.

\section{METHODS}

\section{Preparation of plant extract}

The freshly collected stem bark of the plant Uapaca togoensis was air-dried under shade for 2 weeks. The dried stem bark were pulverized and reduced to powder using a mortar and pestle. The powdered stem bark $(2 \mathrm{~kg}$ ) was exhaustively subjected to cold maceration with $70 \% \mathrm{v} / \mathrm{v}$ methanol for 72 hours with intermittent agitation. The extract was filtered with the aid of a filter paper (Whatman No. 3) and the filtrate was concentrated to dryness at room temperature. The crude methanol extract $(50 \mathrm{~g})$ was further partitioned with $200 \mathrm{ml}$ of ethyl acetate. The resultant filtrate was concentrated to dryness and used for the study.

\section{The parasite Plasmodium berghei}

Plasmodium berghei was obtained from the Department of Microbiology, National Medical Research Institute Yaba, Lagos. The parasite was maintained by continuous re-infestation intraperitoneally in mice every 4 days (Adzuet al., 2007). Before commencing the study, one of the infected mice was isolated and observed to reproduce signs and symptoms of malaria similar to those signs and symptoms exhibited by humans (Ramakirshnan et al., 2012). Each mouse used in the experiment was inoculated with $0.2 \mathrm{ml}$ of infected blood containing about $1 \times 10^{7}$ plasmodium berghei parasitized red blood. This was prepared by determining both the percentage parasitaemia and the erythrocytes count of the donor mouse and diluting them with normal saline in proportion indicated by both determinations (Okonkon et al., 2010).

\section{Acute Toxicity Studies}

The oral median lethal dose of the ethyl acetate fraction of Uapaca togoensis (EAFUT) was determined in mice using the method of Lorke (1983). Animals were fasted overnight prior to administration of the fraction. In the initial phase, three (3) groups each consisting of three mice was treated with the ethyl acetate fraction of the plant at doses of 10, 100 and $1000 \mathrm{mg} / \mathrm{kg}$ body weight orally and observed for signs of toxicity for 4 hours. After 24 hours, the second phase was initiated. In the second phase four groups each containing one animal was administered with four more specific doses of the fraction in geometrically increasing order $(1,200 \mathrm{mg} / \mathrm{kg}, 1,600$ $\mathrm{mg} / \mathrm{kg}, 2,900 \mathrm{mg} / \mathrm{kg}$ and $5,000 \mathrm{mg} / \mathrm{kg}$ ). The animals were then observed for signs of toxicity and mortality for another 24 hours. The $L_{50}$ value was determined by calculating the geometric mean of the lowest dose that caused death and the highest dose for which the animal survived $(0 / 1$ and $1 / 1)$ respectively.

\section{Preliminary Phytochemical Screening}

Phytochemical analysis of the fraction was conducted using standard qualitative method as described by Trease and Evans (2002).

\section{Evaluation of Suppressive Activity in Early Infection (4-day test).}

The method described by Peters and Robinson (1992) was employed.Plasmodium berghei (chloroquine sensitive strain) was used to infect Swiss albino mice for a 4 day suppressive test. A total of thirty mice were used for this study. Each mouse was given standard intra-peritoneal inoculums of $1.0 \times 10^{7} P$. berghei parasites with the aid of a $1 \mathrm{ml}$ disposablesyringe. The animals were divided into five groups of six mice each. Different doses of the ethyl acetate fraction $(250,500,1000 \mathrm{mg} / \mathrm{kg} /$ day $)$ were administered orally to the segroups. Chloroquine 5 $\mathrm{mg} / \mathrm{kg} /$ day was given as positive control and $0.2 \mathrm{ml}$ of distilled water as negative control for four consecutive days (D0 to D3). On the fifth day (D4), thin blood smears were prepared and blood films were fixed with methanol. The blood films were stained with Giemsa, and then microscopically examined with 100-x magnification. The percentage suppression of parasitaemia was calculated for each dose level by comparing the parasitaemia in infected controls with those of treated mice. The slides were examined under the microscope and parasitaemia determined by counting the number of parasitized erythrocytes in four fields. 
Average percentage chemo suppression was calculated as $=(A-B) / A * 100 \%$

Where $A=$ Average parasitaemia in negative control

$B=$ Average parasitaemia in positive groups

Evaluation of Curative Activity in Established Infection (Rane's test).

The method described by Ryley and Peters (1970) was employed. On the first day (day 0 ) of the study, thirty mice were inoculated intraperitoneally with $0.2 \mathrm{ml}$ standard inoculums containing approximately $1 \times 10^{7}$ Plasmodium berghei erythrocytes. Seventy two hours later (day 3), the mice were randomly divided into five groups containing six mice each of both sexes. Group one was administered $0.2 \mathrm{ml}$ of distilled water orally. Groups 2-4 received graded doses of the fraction $(250 \mathrm{mg} / \mathrm{kg}, 500 \mathrm{mg} / \mathrm{kg}$ and $1000 \mathrm{mg} / \mathrm{kg}$ ) while group 5 received $5 \mathrm{mg} / \mathrm{kg}$ of chloroquine (positive control). The fraction and drugs were administered orally daily for 4 days (day $4-7$ ). On day seven, each mouse was tail bled and a thin blood film was made on a microscope slide. The films were fixed in absolute methanol, stained with Giemsa and examined microscopically to determine the parasitaemia level. After the seventh day, the animals were fed ad libitum and observed for 29 days (day 028). Percentage chemo-suppression relative to the negative control was determined for each dose as previously described. Any death that occurred during this period (day 0-28) was noted and the mean survival time (MST) was calculated (Saiduet al., 2000; Adzu and Salawu, 2009; Alliet al., 2011).

MST = (Number of days survived)/ (Total number of days)

Evaluation of Prophylactic (repository) Activity The prophylactic activity of the extract was investigated using the method described by Peters (1965). 30 mice of both sexes were randomly divided into five groups each containing six mice. Group 1 was administered with $0.2 \mathrm{ml}$ distilled water, groups 2, 3 and 4 were administered with 250, 500 and 1000 mgfraction / $\mathrm{kg}$ body weight orally respectively, while group 5 was administered with $1.2 \mathrm{mg}$ pyrimethamine/kg body weight orally daily. Treatment continued daily for three days $\left(D_{1}-D_{3}\right)$ and mice were all infected with the parasite on the fourth day $\left(D_{4}\right)$. Thin blood films were prepared from each mouse 72 hours $\left(D_{7}\right)$ post treatment and mean parasitaemia in each group determined microscopically. Thin blood films stained with Giemsa stain were prepared from tail blood of each mouse and percentage chemo suppression calculated according to the formula stated previously.

\section{Statistical Analysis}

Data were expressed as mean \pm standard error of mean (SEM). Statistical analysis was carried out using one way analysis of variance (ANOVA) followed by
Dunnett t-test. Results were considered to be significant at $p<0.05$.

\section{RESULTS}

Preliminary Phytochemical Screening

The ethyl acetate fraction of the stem bark of Uapaca togoensis comprised of glycosides, phenols, triterpenes, steroids, alkaloids, tannins, carbohydrates, saponins and flavonoids (Table 1).

\section{Acute Toxicity Studies}

The median oral lethal dose of the stem bark extract of Uapacatogoensis in mice was found to be greater than $5000 \mathrm{mg} / \mathrm{kg}$ body weight. There was a remarkable increase in activity in the mice within the first four hours. Nomortality occurred within the observation period of 48 hours.

\section{Antiplasmodial Activity}

Effect of Suppressive Activity of the Ethyl Acetate Fraction of the Stem Bark $U$. togoensis The administration of the fraction resulted in a significant dose-dependent decrease in parasite counts. The average parasite percentage chemo suppression recorded was $39.1,53.9$ and $72.7 \%$ at 250, 500 and 1000 mgextract/kg body weight, respectively, while administration of thestandard reference drug (Chloroquine $5 \mathrm{mg} / \mathrm{kg}$ body weight) produced $98 \%$ chemo suppression (Table 2 ).

Schizonticidal Activity of the Ethyl Acetate Fraction of the Stem Bark of $\boldsymbol{U}$. togoensis

The administration of the fraction also resulted in significant and dose dependent decrease in parasite counts in the treated groups when compared to the control group (Table 3 ). The mean parasite count was 15,9 and 4, at the doses of 250, 500 and $1000 \mathrm{mg} / \mathrm{kg}$ bodyweight, respectively, as compared with the mean parasite count of 23.25 in the negative control group. Chloroquine administration of $5 \mathrm{mg} / \mathrm{kg}$ chloroquine reduced the mean parasitedensity to 0.1 . The dose of extract administered alsoaffected the survival period of the mice. Mean survival time in the distilled water treated group was 10 days. Mice administered with 250, 500 and $1000 \mathrm{mg}$ extract $/ \mathrm{kg}$ body weight survived for 28, 25 and 24 days respectively. Chloroquine administered mice had survival of 28days after administration similar to the mice treated with $250 \mathrm{mg}$ extract/kg body weight (Table 4).

Prophylactic Activity of the Ethyl Acetate Fraction of the Stem Bark of $\boldsymbol{U}$. togoensis

There was a dose dependent prophylactic activity at the doses employed resulting in a significant reduction in extract treated group when compared to the control. Average percentage chemosupression of $31.4,58.2$ and $73.1 \%$ was respectively recorded for the corresponding doses of extract (250, 500 and $1000 \mathrm{mg} / \mathrm{kg} /$ day). Percentage chemosupression exerted by the standard drug (pyrimethamine1.2mg/kg/day) was $99.2 \%$ (Table 5 ). 
Table 1: Phytochemical Constituents present in the Fraction

\begin{tabular}{lc}
\hline Phytochemical constituent & \\
\hline Carbohydrates & + \\
Glycosides & + \\
Anthraquinones & - \\
Steroids/triterpenes & + \\
Cardiac glycosides & + \\
Saponins & ++ \\
Tanins & + \\
Flavonoids & + \\
Alkaloids & + \\
\hline
\end{tabular}

$+=$ present $\quad-=$ absent

Table 2: Suppressive Activity of Ethyl Acetate Fraction of $\boldsymbol{U}$. togoensis

\begin{tabular}{lclll}
\hline $\begin{array}{l}\text { Treatment } \\
\text { (Oral) }\end{array}$ & Group & Dose $(\mathrm{mg} / \mathrm{kg} /$ day) & Average parasitemia & $\begin{array}{l}\text { Average } \\
\text { chemosupression }(\%)\end{array}$ \\
\hline Distilled water & 1 & $0.2 \mathrm{ml}$ & $30.83 \pm 1.90$ & \\
EAF & 2 & 250 & $18.50 \pm 4.93^{*}$ & 39.1 \\
EAF & 3 & 500 & $14.00 \pm 2.87^{*}$ & 53.9 \\
EAF4 & & 1000 & $8.30 \pm 1.55^{*}$ & 72.7 \\
Chloroquine 5 & & 5 & $0.67 \pm 0.33^{*}$ & 97.8 \\
\hline
\end{tabular}

Values were presented as mean $\pm S E M, n=6$, values were significantly different between test and control group at $* \mathrm{p}<0.05, \mathrm{EAF}=$ Ethyl Acetate Fraction

Table 3: Curative Activity of Ethyl Acetate Fraction of $\boldsymbol{U}$. togoensis

\begin{tabular}{|c|c|c|c|c|}
\hline $\begin{array}{l}\text { Treatment } \\
\text { (Oral) }\end{array}$ & Group & Dose (mg/kg/day) & Average parasitemia & $\begin{array}{l}\text { Average percentage } \\
\text { chemosupression (\%) }\end{array}$ \\
\hline Distilled water & 1 & $0.2 \mathrm{ml}$ & $23.25 \pm 1.78$ & \\
\hline EAF 2 & & 250 & $15.13 \pm 1.62 *$ & 34.9 \\
\hline EAF 3 & & 500 & $9.35 \pm 3.09 *$ & 59.8 \\
\hline EAF4 & & 1000 & $4.15 \pm 0.49 *$ & 82.2 \\
\hline Chloroquine5 & & 5 & $0.10 \pm 0.08^{*}$ & 99.6 \\
\hline
\end{tabular}

Values were presented as mean \pm SEM, $n=6$, values were significantly different between test and control group at $* \mathrm{p}<0.05, \mathrm{EAF}=$ Ethyl Acetate Fraction

Table 4: Mean Survival Time of mice

\begin{tabular}{|c|c|c|c|}
\hline Treatment (Oral) & Group & Dose (mg/kg/day) & Mean survival time (days) \\
\hline Distilled water1 & & $0.2 \mathrm{ml}$ & $10.00 \pm 3.73$ \\
\hline EAF 2 & & 250 & $28.00 \pm 0.00$ \\
\hline EAF3 & & 500 & $25.30 \pm 0.00$ \\
\hline EAF4 & & 1000 & $24.70 \pm 3.83$ \\
\hline Chloroquine5 & & 5 & $28.00 \pm 0.00$ \\
\hline
\end{tabular}

Values were presented as mean $+\mathrm{SEM}, \mathrm{n}=6$, values were significantly different between test and control group at $* \mathrm{p}<0.05, \mathrm{EAF}=$ Ethyl Acetate Fraction

Table 5: Prophylactic Activity of Ethyl Acetate Fraction of $U$. togoensis

\begin{tabular}{lclcc}
\hline $\begin{array}{l}\text { Treatment } \\
\text { (Oral) }\end{array}$ & Group & Dose $(\mathrm{mg} / \mathrm{kg})$ & Average parasitaemia & $\begin{array}{c}\text { Average } \\
\text { chemosupression }(\%)\end{array}$ \\
\hline Distilled water & 1 & $0.2 \mathrm{ml}$ & $21.37 \pm 1.35$ & - \\
EAF & 2 & 250 & $14.65 \pm 0.99$ & 31.4 \\
EAF & 3 & & $8.94 \pm 2.17$ & 58.2 \\
EAF & 4 & 1000 & $5.75 \pm 1.25$ & 73.1 \\
Pyrimethamine5 & & 1.2 & $0.18 \pm 0.12$ & 99.2 \\
\hline
\end{tabular}

Values were presented as mean $+S E M, n=6$, values were significantly different between test and control group at $* \mathrm{p}<0.05, \mathrm{EAF}=$ Ethyl Acetate Fraction

\section{DISCUSSION}

The in vivo antiplasmodial activity and acute toxicity of the ethyl acetate fraction of Uapacatogoensis stem bark extract was investigated. Acute toxicity studies of the ethyl acetate fraction were carried out to determine the safety of the fraction. The oral median lethal dose $\left(\mathrm{LD}_{50}\right)$ of the fraction was greater than $5000 \mathrm{mg} / \mathrm{kg}$ body weight. This suggests that acute oral administration of the fraction is relatively safe (Lorke, 1983). Rodent models have been shown to produce disease features similar to those of human plasmodial infection, when infected with $P$. berghei (Thomas et al., 1998). Many studies have employed $P$. berghei in predicting treatment outcome of suspected antimalarial agents, because of its high sensitivity to chloroquine (Agbedahunsi, 2000; Adzu and Salawu 2009). Thus $P$. berghei infected mice was used in this study.

The 4 day suppressive test is a standard test commonly used for antimalarial screening (Peters, 1965). 
The ethyl acetate fraction produced significant dose related chemo suppression in all the treated groups with the highest chemo suppression (73\%) observed in the group treated with $1000 \mathrm{mg}$ fraction $/ \mathrm{kg}$. The chemo-suppression value of the highest dose of the fraction was much higher than that of the lower doses indicating that the fraction has more suppressive activity at higher doses. The fraction also demonstrated significant dose related reduction in parasite count in both established(curative) and residual (repository) infection, comparable to the effect of chloroquine and pyrimethamine, which in this study were usedas standard control drugs. For the mean survival time, mice administered with the lowest dose of the fraction $(250 \mathrm{mg} / \mathrm{kg}$ ) survived for 28 days comparable to the number of days to the chloroquine treated mice.

The mechanism by which the ethyl acetate fraction exerts its antiplasmodial action has not been elucidated; however, antiplasmodial effects of natural plant products have been attributed to some of their active phytochemical components (Sofowora, 1980;Ayoolaet al., 2008). Some of these phytochemicals such as terpenes and flavonoids have been reported to have antiplasmodial activity (Phillipson and Wright, 1990; Christensen and

\section{REFERENCES}

Addis, G., Abebe, D. and Urga, K. (2001). A survey of traditional medicine in Shirka District, Arsi Zone, Ethopia. Ethiop Pharm J. 19: 30-47.

Agbedahunsi, J. M. (2000). Screening of crude drugs for the treatment of malaria in Nigeria, Phytomedicine in malaria and sexually transmitted diseases: Challenges for the new millennium. Drug Research and Production Unit, Faculty of pharmacy, ObafemiAwolowo University, Ile Ife, Nigeria, pp. 13-22.

Adzu, B., Haruna, A.K., Salawu, O. A., Katsayal, U. A. and Nian, A. (2007). In-vivo antiplasmodial activity of ZS-2A: a fraction from chloroform extract of Zizyphusspina Christy root bark against $P$. bergheiberghei in mice. International Journal of biology and Chemical Science. 1(3): 281-286.

Adzu, B. and Salawu, O. A. (2009). Screening Diospyrosmespiliformis extract for antimalarial potency. Int. J. Biol. Chem. Sci., 3(2): 271-276.

Alli, L. A., Adesokan, A. A., Salawu, O. A., Akanji, M. A. and Tijani A. Y. (2011). Anti plasmodial activity of aqueous root extract of Acacia nilotica. African Journal of Biochemistry Research, 5: 214219.http://www.academicjournals.org/AJBR

Ajibesin, K. K. (2012). Ethnobotanical survey of plants used for skin diseases and related ailments in AkwaIbom State, Nigeria. Ethnobotany Research \& Applications, 10:463-522. www.ethnobotanyjournal.org/vol10/i15473465-10-463.pdf
Kharazmi, 2001; Go,2003). Preliminary phytochemical screening of the ethyl acetate fraction of Uapacatogoensis stem bark revealed the presence of glycosides, phenols, triterpenes, steroids, alkaloids, tannins, carbohydrates, saponins and flavonoids. The antiplasmodial effect of ethyl acetate fraction of $U$. togoensismay therefore be due to the presence of one or all of the phytochemical components present.

\section{CONCLUSION}

The findings from the study suggest that the ethyl acetate fraction of Uapacatogoensis possesses antiplasmodial activities, and supports the ethno medical claim of the use of theplant in the management of malaria and fever.

\section{CONFLICT OF INTEREST}

There is no conflict regarding this work.

\section{CONTRIBUTION OF AUTHORS}

$O A B$ designed and carried out the work under the supervision of MBB, CBA AND EJI. HAN was consulted when $O A B$ was writing the paper.

\section{Acknowledgement}

We are grateful to the authorities of the Department of Pharmacology and Therapeutics, Ahmadu Bello University, Zaria for providing the facilities for conducting this research.

Ayoola, G. A., Coker, H. A, B., Adesegun, S. A., Adepoju-Bello, A. A., Obaweya, K., Ezennia, E. C. and Atangbayila, T. O. (2008). Phytochemical screening and antioxidant activities of some selected medicinal plants used for malaria therapy in southwestern Nigeria. Trop. J. Pharm. Res., 7(3):10191024

Basco, L.K., Mitaku, S., Skaltsounis, A.L., Ravelomanaintsoa, N., Tillequin, F., Koch, M., Le Bras, J., (1994). In vitro activities of acridone alkaloids against Plasmodium falciparum. Antimicrobial Agents and Chemotherapy. 5:1169-1171.

Burkill, H. M. (1994). The useful plants of West Tropical Africa, 2nd Edition. Volume 2. Families E-I, Royal Botanic Gardens, Kew, Richmond, United Kingdom. p636.

Christensen, S. B. and Kharazmi, A. (2001). Antimalarial natural products: isolation, characterization and biological properties. In Bioactivecompounds from natural sources: Isolation, Characterization and Biological Properties, Tringali C (ed). Taylor and Francis: London.p90-98.

Collins, W. E. (2012). Plasmodium knowlesi: a malaria parasite of monkeys and humans". Annu Rev Entomol; 57:107-121. PubMed Abstract | Publisher Full Text OpenURL

Go, M. L. (2003). Novel antiplasmodial agents. Med. Plant Rev, 23: 456-487

Horeau, L. and Dasilva, E. J. (1999). Medicinal plants: a re-emerging health aid. Electronic Journal of Biotechnology. 2: 56-69. 
Igwe, C. U., Ojiako, A. O., Emejulu, A. A. and Iwueke, A. V. (2012). Phytochemical analysis of plants traditionally used for malaria treatment in South eastern Nigeria. Journal of Research in Biochemiostry. 1: 15-22.

Irvine, F.R. (1948). The Indigenous Food Plants of West African Peoples, New York Botanic Garden Journal. 49: 225-36.

Iwuanyanwua, T. C., Akuodorb, G. C., Essienb, A. D., Nwinyic, F. C., Akpand, J. L., Okorafore, D. O. and Osunkwoa, U. A. (2012). Evaluation of antimalarial potential of aqueous stem bark extract of Bombaxbuonopozense P. Beauv. (Bombacaceae). Eastern Journal of Medicine 17: 72-77.

Koné, W. M., Atindehou, K. K., Terreaux, C., Hostettmann, K., Traoré, D. and Dosso, M. (2004). Traditional medicine in North Côted'Ivoire: screening of 50 medicinal plants for antibacterial activity. Journal of Ethnopharmacology, 93:43-49. DOI: 10.1016/j.jep.2004.03.006

Kuete, V., Sandjo, L. P., Seukep, J.A., Zeino, M., Mbaveng, A. T., Ngadjui, B. and Efferth, T. (2015). Cytotoxic Compounds from the Fruits of Uapacatogoensis towards Multifactorial Drug-Resistant Cancer Cells. Planta Med. 81(1):32-8. doi: 10.1055/s-0034-1383362.

Lorke, D. (1983). A new approach to acute toxicity testing. Archives of toxicology, 54: 275-287.

Mendis, K., Sina, B. J., Marchesini, P. and Carter, R. (2001). The neglected burden of $P$. vivax malaria. Am. J. Trop Med. Hyg. 64: 97.

Odugbemi, T. O., Akinsulire, R. O., Aibinu, I. E. and Fabeku, P. O. (2007). Medicinal plants useful for malarial therapy in Okeigbo, Ondo State, Southwest Nigeria. African Journal Traditional Complementary and Alternative Medicine, 4: 191-198.

Okokon, J. E. and Nwafor, P. A. (2010). Antiinflammatory, analgesic and antipyretic activities of ethanolic root extract of Croton zambesicus. Pakistan Journal of Pharmaceutical Sciences. 23: 383-390.

Omachi, A. A., Ndukwe, G. I., Sallau, M. S. and Ayo, R. G. (2015). Phytochemical screening and antimicrobial studies of Uapacatogoensis (pax) stem bark extracts. The International Journal of Engineering and Science, 4:24-28.

Peters, W. (1965). Drug resistance in Plasmodium berghei. Vinka and Lips. Experimental. Parasitology. 17: 80-89.
Peters, W. and Robinson, B. L. (1992). The chemotherapy of rodent malaria XLVII. Studies on puronaridine and other manich base anti-malaria. Annals of tropical medicine and parasitology, 86: 455-465.

Phillipson, J. D. and Wright, C. W. (1990). Can ethno pharmacology contribute to the development of antimalarial agents? Journal of Ethnopharmacology, 32:155-165

World Health Organization (2002). Traditional Medicine Strategy 2002-2005. WHO Publications, pp: 1-6.

World Health Organization (2015). Fact sheet No. 94. Reviewed December 2015.

Ramakrishnan, C., Delves, M. J., Lal, K., Blagborough, A. M., Butcher, G., Baker, K.W. and Sinden, R.E. (2012). Laboratory maintenance of rodent malaria parasites. Methods in Molecular Biology. 923: $51-72$.

Ryley J.F. and Peters W (1970). The Antimalarial activity of some quinoline esters. Annals of Tropical Medicine and Parasitology 64: 209222.

Sarkar, P. K., Ahluwalia, G., Vijayan, V. K. and Talwar, A. (2009). Critical care aspects of malaria. $J$ Intensive Care Med, 25:93-103. PubMed Abstract Publisher Full Text OpenURL

Saidu, K., Onah, J., Orisadipe, A., Olusola, A., Wambebe, C. and Gamaniel, K. (2000). Antiplasmodial, analgesic and antiinflammatory activities of the aqueous stem bark of Erythrinasenegalensis. Journal of Ethnopharmacology, 71: 275-280.

Sofowora, A. (1980). The present status of knowledge of the plants used in traditional medicine in West Africa: A medical approach and a chemical evaluation. J. Ethno. Pharmacol., 2: 109-118.

Tcherniuk, S. O., Chesnokova, O., Oleinikov, I. V., Potopalsky, A. I. and Oleinikov, A. V. (2015). Anti-malarial effect of semi-synthetic drug amitozyn. Malaria Journal, 14:425 doi: 10.1186/s12936-015-0952-4

Thomas, A. M., Van Der Wel, A. M., Thomas, A. W., Janse, C. J. and Waters, A. P. (1998). Transfection system for animal models of malaria. Parasitol. Today, 14: 248-249.

Trease, G. E. and Evans, W.C. (2002) Pharmacognosy $13^{\text {th }}$ Edition, Balliere, Tindall and Cansell Ltd. London p191-293. 